\title{
人工膝関節置換術患者における非術側の 筋力と関節可動域の基準範囲
}

\author{
Reference Intervals of Muscle Strength and Motion Range of the Knee Joint \\ on the Side Opposite to Knee Arthroplasty
}

\author{
伊藤 秀幸 ${ }^{1,2}$ 市原 清志 $^{2)}$ 天野 徹哉 ${ }^{3)}$ \\ Hideyuki ITO, MS ${ }^{1,2)}$, Kiyoshi ICHIHARA, MD, $\mathrm{PhD}^{2)}$, Tetsuya AMANO, $\mathrm{PhD}^{3)}$ \\ ${ }^{1)}$ Department of Rehabilitation, Faculty of Wakayama Health Care Sciences, Takarazuka University of Medical and Health Care: \\ 2252 Nakanoshima, Wakayama-shi, Wakayama 640-8392, Japan TEL +81 73-494-5000 E-mail: h-ito@tumh.ac.jp \\ 2) Graduate School of Medicine, Yamaguchi University \\ ${ }^{3)}$ Department of Physical Therapy, Faculty of Health and Medical Sciences, Tokoha University
}

Rigakuryoho Kagaku 36(2): 159-168, 2021. Submitted Oct. 2, 2020. Accepted Oct. 27, 2020.

ABSTRACT: [Purpose] The assessment of non-operative knee function is important for the recovery of activities of daily living (ADL) of patients with knee arthroplasty. Therefore, we established reference intervals (RIs) for knee muscle strength and range of motion, taking into account the factors that affect values before and after surgery. [Participants and Methods] We evaluated knee muscle strength and range of motion in knee extension and flexion, as well as knee extension and flexion joint range of motion in 390 patients who had undergone knee arthroplasty, excluding those who had undergone the same surgery on the opposite side. The partitioning of RI by these factors was judged using the standard deviation ratio (SDR) representing the magnitude of between-subgroup differences. Variables were evaluated, and the SDR was calculated, and 0.3 was used as a stratification criterion. [Results] From the SDR values, it was judged that each muscle strength and each range of motion should be stratified by gender and by whether the knee arthropathy was unilateral or bilateral. The RIs were established using the Box-Cox parametric method for muscle strength and by a nonparametric method for range of motion. [Conclusion] The reference range of non-operative knee function is useful for evaluating knee function before and after surgery.

Key words: Box-Cox formula, standard deviation ratio (SDR), multiple regression analysis

要旨：〔目的〕人工膝関節置換術患者における日常生活活動（ADL）の回復には, 非術側の膝機能評価は重要であ る。そのため膝筋力と関節可動域の基準範囲を, 術前後の值に影響する要因を考慮して設定する.〔対象と方法〕人 工膝関節置換術患者のうち反対側に同手術の既往があるものを除いた 390 名を対象とし, 膝伸展 ·屈曲筋力と伸展 · 屈曲関節可動域を測定した。変動要因の評価を実施し，群間差指数（SDR）を算出し，0.3を層別化の基準とした。 〔結果〕SDR 值から, 各筋力は性別により, 各関節可動域は膝関節症が片側性か両側性かにより層別化が必要と判断 した，筋力は Box-Cox 式のパラメトリック法により，関節可動域はノンパラメトリック法により基準範囲を設定した 〔結語〕非術側の膝機能の基準範囲は, 術後患者の膝機能評価に役立つ.

キーワード：Box-Coxべき乗変換式, 群間差指数 (SDR), 重回帰分析

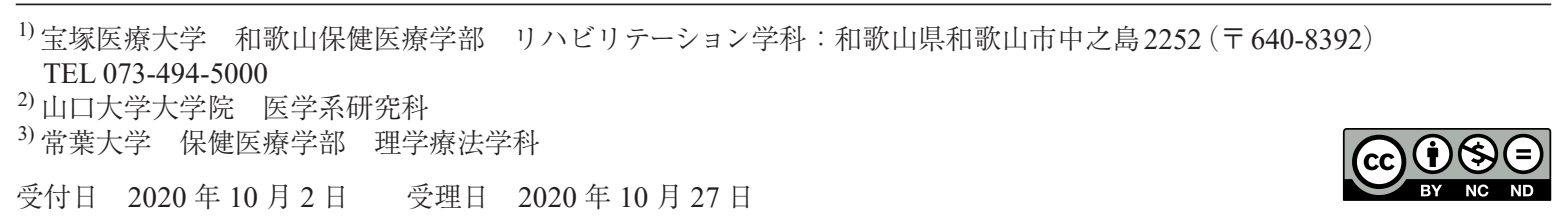




\section{I. はじめに}

大規模住民コホート研究により報告された変形性膝関 節症（以下, 膝 $\mathrm{OA}$ ）の有病率は非常に高く, 膝 $\mathrm{OA}$ 患 者数は 2530 万人, また有症状患者数は約 800 万人と推 定されている 1). 膝 $\mathrm{OA}$ 患者の疼痛や運動機能の改善を 認めない場合は, 人工膝関節全置換術（以下, TKA) や単顆型人工膝関節置換術（以下, UKA）が実施され て㧍り，その手術件数も年間 8 万 2 千件 2) にのぼって いる.

TKA や UKA の実施による運動機能や quality of life （QOL）の改善には, 術後早期の膝筋力ゃ関節可動域が 影響することが報告されている ${ }^{3)}$. 一方で, 片側性の人 工膝関節置換術患者に打いて, 非術側の膝関節筋力や関 節可動域が, 術後の運動機能や日常生活動作能力に影響 することが示唆されている.Zeniら ${ }^{4)} は$, 片側膝に TKA を実施した 155 名を対象に調查を実施し, TKA 術 後早期の非術側の大腿四頭筋筋力が, 術後 1 年と 2 年時 点の日常生活能力の指標である Activities of Daily Living Scaleに影響していたと報告している。また Valtonen ら 5) は, 片僋膝に TKA を実施した 48 名を対 象に調査を実施し, TKA 術後 4 18 カ月時点に扔いて, 非術側の滕屈曲筋力が階段昇降能力に影響していたと報 告した。さらに内田ら 6)は, TKA と UKA 術後の運動 機能には, 術前の非術側の膝伸展可動域が重要な役割を 果たしたと報告している。すすおち非術側の膝筋力や膝 関節可動域は, 術後の運動機能や生活動作能力を改善さ せるうえで重要となる，そのため術前と術後早期におい て, 非術側の膝筋力と関節可動域を評価することは, 人 工膝関節置換術患者に対し, より良い術後管理を実施す るうえで重要となる.

非術側の筋力と関節可動域を検査・測定した際に, 測 定值の良し悪しを判断する基準となる值（基準值）や測 定值の中央 $95 \%$ 区間を示す「基準範囲」が必要である. 箱力の基準值については, Danneskiold-Samsøe ら7) が健常者を対象に，年齢と性別により層別化した等尺 性・等速性膝筋力の平均值と中央値を報告した。また Andrews $5^{8)}$ は, 健常者を対象に, 等尺性·等速性膝 筋力の平均値と標準偏差を報告した。 しかし, これらの 報告は, 計測值が正規分布であるかが考慮されていない ため, 平均值と標準偏差からは適切な基準範囲は求まら ない.

そして関節可動域測定の参照值として, 日本整形外科 学会と日本リハビリテーション医学会による関節可動域 測定の参考可動域が報告された ${ }^{9}$ ，報告によると，関節 可動域は年齢・性・肢位・個体による変動が大きいため, 基準範囲は定めず参考可動域として記載している。 その ため, 測定值の変動要因の分析と層別化の妥当性を検討 する必要性があるが，検討が不十分といえる，そして健
常者と病態を有する膝 $\mathrm{OA}$ 患者とでは, 筋力や関節可動 域に乘離を認めることから，非術側に㧈いても膝 $\mathrm{OA}$ 患 者に固有な筋力や関節可動域の基準範囲が必要となる.

本研究では, 片側にTKA またはUKAを受けた膝 $\mathrm{OA}$ 患者を対象に, 非術側の膝運動機能として, 膝筋力 と関節可動域の術前後の值に影響する要因を検討した。 また明らかになった各測定値の変動要因の意義は, 測定 值の層別化図により確認し, 健常者の值と非術側の值を 比較した。さらに, 変動要因で層別化した非術側の各膝 運動機能に対する基準範囲を設定することにより, 術前 後のリハビリテーションに扮ける機能評価の的確な運用 をめざした，最後に，基準範囲の設定では，分布型を考 慮した信頼性の高い手法 ${ }^{10)}$ を採用した.

\section{II. 対象と方法}

\section{1. 対象}

対象は, 研究協力が得られた 13 施設 (近畿地方 1 施 設. 中国地方 5 施設・四国地方 4 施設 $\cdot$ 九州地方 3 施設) に扔いて, TKA またはUKAの適用になった膝 OA患 者のなかで, 片側性の人工膝関節置換術患者 390 名を 対象とした。対象者の基本・医学的属性は表 $1 \mathrm{a}$ に示す. 包含基準は，1）滕 OA と診断され，2）TKA および UKA の適用例とした。除外基準は，1）運動麻痺など の神経学的所見を認めた者，2）滕関節以外の関節可動 域制限や疼痛が著明で, 立ち上がり, 歩行動作の制限に なっていた者，3）認知機能障害，精神機能障害を有す る者とした，患者は，13 施設で概ね共通して実施され ているリハビリテーションプログラムに基づくクリニカ ルパスに従って管理され, 術後退院予定日は21日で あった、リハビリテーションプログラムは，1）膝関節 可動域運動，2）大殿筋，中殿筋，大腿四頭筋の筋力増 強運動，抢よび 3）日常生活動作練習（立ち上がり動作, 歩行, 階段昇降）によって構成されていた.

また年齢が膝 OA 患者と同等の 120 名（男性 36 名, 女性 84 名）の健常高齢者を募集した。対象者の基本属 性は表 $1 \mathrm{~b}$ に示す. Bohannon ら 11)の報告に基づいて採 用した包含基準は，1）健康と自覚し，日常生活活動を単 独で何ら不自由なく過ごせること，2）現在，運動器疾患， 神経筋疾患, 心疾患に対して通院治療中でないこと, 3）滕関節や股関節などに人工関節置換術の既往がない こと，4） $30 \mathrm{~m}$ を補助なしで歩行ができることとした。

\section{2. 方法}

研究デザインは, 滕 OA 患者に打ける膝関節の筋力と 関節可動域の基準範囲を確立することを目的とした前向 きコホート研究とした．性別, 年齢, Body Mass Index (以下, BMI), 定期的な運動習慣の有無, 非術側膝の障 害（片側性・両側性）をアンケートとカルテより調查し 
表 1 膝 $\mathrm{OA}$ 患者と健常者の属性

\begin{tabular}{|c|c|c|}
\hline & a. 膝 OA 患者 & b. 健常高齢者 \\
\hline 性別（男／女） & $98 / 292$ & $36 / 84$ \\
\hline 年齢（歳）（男／女） & $74.3 \pm 8.8 / 73.8 \pm 7.5$ & $72.3 \pm 5.9 / 70.9 \pm 6.0$ \\
\hline BMI（kg/m²）（男／女） & $25.1 \pm 3.5 / 25.3 \pm 3.8$ & $23.2 \pm 2.4 / 22.1 \pm 3.1$ \\
\hline 運動習慣（名） & あり $: 123$, なし $: 267$ & あり：99, なし：21 \\
\hline OA 重症度（名） & Grade $2: 25$, Grade $3: 179$, Grade $4: 186$ & \\
\hline 術式（名） ～～～～～～～名 & 従来式-TKA：75, MIS-TKA：238, UKA：77 & \\
\hline 非術側膝の障害（名） & 片側性 : 159, 両側性 : 231 & \\
\hline
\end{tabular}

膝 OA：変形性膝関節症, BMI：Body Mass Index, TKA：人工膝関節全置換術, MIS-TKA：低侵襲人工滕関 節全置換術, UKA：単顆型人工膝関節置換術.

た。定期的な運動習慣は, 週 2 回以上·30 分以上の運 動を運動習慣があると定義した。

膝筋力と関節可動域は術前と術後 14 日目に測定を実 施した，膝伸展筋力は，ハンドヘルドダイナモメーター (以下，HHD）（ $\mu$ TasF-1，アニマ社製）を用いて以下の 手順で測定を実施した。測定肢位は端座位にて，測定者 は対象の下肢をべルトで固定し, 膝関節屈曲 $90^{\circ}$ の位置 になるようにした。 そして対象者に最大の力により膝を 伸ばすように指示した，HHDの出力 $(\mathrm{N})$ とアーム長 （m）の積であるトルク（Nm）を算出し，その值を対象 者の体重で（kg）で除したトルク体重比（Nm/kg）を筋 力值とした。アーム長の測定は膝関節外側裂隙から下腿 遠位部前面のセンサー部中央の長さを測定した ${ }^{12)}$ 。最 大等尺性筋力を 2 回測定し，その平均值を採用した。膝 屈力筋力も同様の測定肢位に実施した．膝伸展筋力との 違いは, HHDのセンサーが足関節後方に装着され, 対 象者に最大の力により膝を曲げるように指示した ${ }^{12)}$.

膝関節の屈曲・伸展関節可動域は, 日本整形外科学会 と日本リハビリテーション医学会が共同で発行したガイ ドライン 9)に従い，関節角度計により測定した。脛骨 の長軸と大腿骨の長軸の角度を 5 ○単位で測定した。

統計解析は, 術前と術後における非術側の膝筋力と関 節可動域に関連する要因を特定するため, 重回帰分析を 実施した。目的变数には, 非術側の膌伸展筋力, 膝屈曲 筋力, 膝伸展可動域, 膝屈曲可動域の值を, 説明変数に は, 性別, 年齢, BMI, 定期的な運動習慣（なし：0, あり：1）, および非術側の障害（片側性：0, 両側性：1） を，分析対象とした。筋力や関節可動域の測定值間の比 較を容易にするために，目的変数によらず，全ての説明 変数を固定して分析した. 各説明変数の有意性は, サン プルサイズが大きいため, $\mathrm{p}$ 值ではなく標準偏回帰係数 （rp）を目安とした。 そして，その効果量として，相関 係数に対するCohenの効果量である,「小さい」 $\mathrm{rp}=0.1$ および「中等度」 $\mathrm{rp}=0.3$ の中間值である $|\mathrm{rp}| \geq 0.2$ を 有意な効果量とみなした ${ }^{13)}$ ，また明らかになった各測 定值の変動要因の意義は, 測定值の層別化図により確認
し，さらに健常者の值と非術側の值を比較した。

基準範囲を層別化するための要因として, 性別, 年齢, BMI，および非術側の障害の有無について検討した。術 前と術後の測定值について, それぞれ性別, BMI, 両側 性の 3 因子を設定し，3レベルの枝分かれ分散分析を実 施した。さらに術後の測定值については，BMIを年齢 に置き換えた形での分析も2 次的に実施した。これら要 因の選択は, 重回帰分析の結果に基づいて決定した（結 果を参照).

分析において, 年齢は 70 歳と 80 歳にて分割し, BMI はWHOの基準である $18.5,25,30 \mathrm{~kg} / \mathrm{m}^{2}$ に分割し層 別化を行った，層別化後の群間差の程度を調べるため, 枝分かれ分散分析により, 各要因の変動の大きさを標準 偏差（以下, SD）の形で, 個体間変動（個体間 SD）, 性別間 SD, 年齢間 SD, BMI 間 SD, および両側性間 $\mathrm{SD}$ を算出した。各要因の SDの相対的な大きさは, 個 体間 SD に対する比（SD 比：SDR）を SDR として算出 した. SDRは群間差指数とも呼ばれ, 既報のごとく

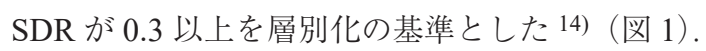

基準範囲は，調整 Box-Cox べき乗変換式を用いて正 規分布へ変換するパラメトリック法10)により設定した (図 2).

$$
X=\frac{(x-\alpha)^{p-1}}{p}
$$

$\mathrm{X}$ は測定值 $\mathrm{x}$ の変換された值を表し, $\mathrm{p}$ と a はそれぞ れ最尤法を利用した非線形回帰処理法で推定されるべき 乗值と変換原点を表す。変換後の $95 \%$ 信頼区間 $\left(\mathrm{LL}^{\mathrm{T}}\right.$. $\left.\mathrm{UL}^{\mathrm{T}}\right)$ は, 変換された測定值の平均值 $\left(\mathrm{m}^{\mathrm{T}}\right)$ と標準偏差 $\mathrm{SD}\left(\mathrm{SD}^{\mathrm{T}}\right)$ を使用して次のように計算した。

$$
\mathrm{LL}^{\mathrm{T}}=\mathrm{m}^{\mathrm{T}}-1.96 \mathrm{SD}^{\mathrm{T}} \quad \mathrm{UL}^{\mathrm{T}}=\mathrm{m}^{\mathrm{T}}+1.96 \mathrm{SD}^{\mathrm{T}}
$$

次に, 元の測定值 $(\mathrm{LL} \cdot \mathrm{UL})$ の下限值と上限值を次 の式を使用して逆変換することで計算した.

$$
\mathrm{LL}=\left(\mathrm{p} \times \mathrm{LL}^{\mathrm{T}}+1\right)^{1 / p}+\mathrm{a} \quad \mathrm{UL}=\left(\mathrm{p} \times \mathrm{UL}^{\mathrm{T}}+1\right)^{1 / p}+\mathrm{a}
$$

正規変換の成功は, 正規確率紙における累積度数曲線 の線形性と, 正規性の Kolmogorov-Smirnov 検定（K-S test）によって確認した。 また仮に正規変換できない場 
1 年齢群間差SDを, 年齢群別平均の

1 総平均からの変動として算出

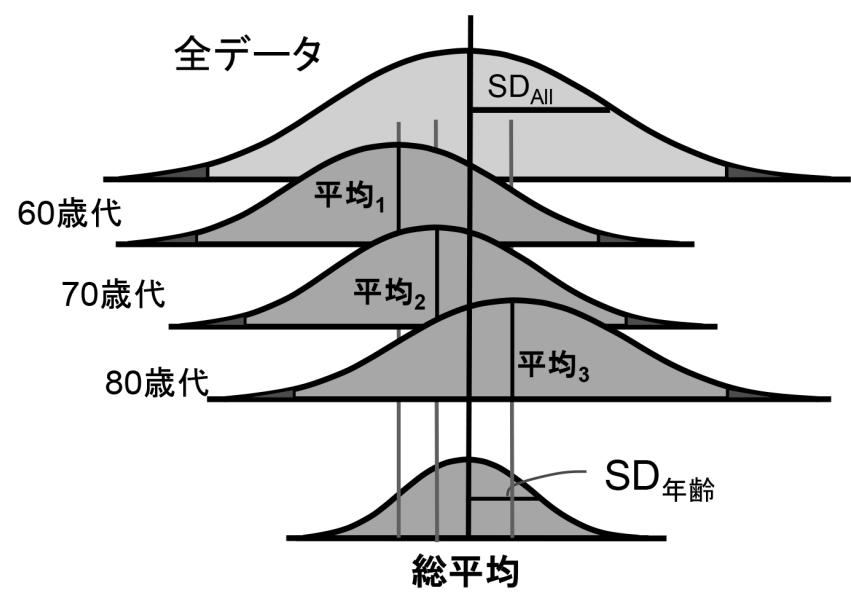

$\mathrm{SD}_{\text {年齢 }}:$ 年代別平均の総平均からのSD
2 各年齢群の平均值を, 総平均に揃えて, 個体間SDの平均的な値を求める

総平均

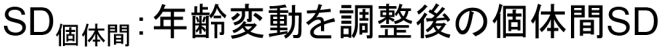

$$
\mathrm{SDR}_{\text {年齢 }}=\frac{\mathrm{SD}_{\text {年齢 }}}{S D_{\text {個体間 }}}
$$

図1 SD比・SDRの概念図

各要因による変動と検查值との関連の強さを表す $\mathrm{SD}$ 比・SDRを要因間 SD／個体間 SDにより算出する，概念図では，年 齢のSDRの計算例を示す．SD：標準偏差, SDR：群間差指数.

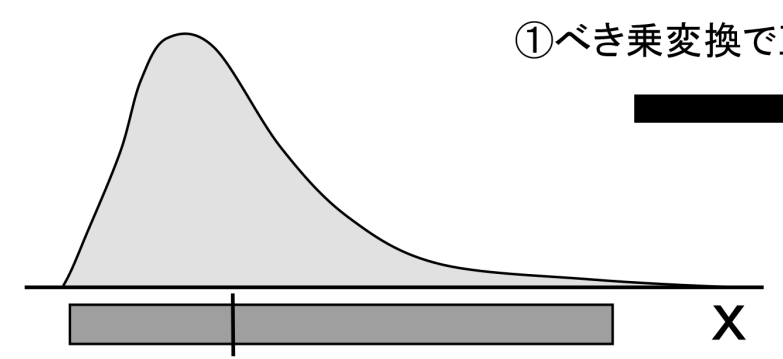

LL $\quad$ Me

$\left(L^{\top}\right)^{1 / p}$
UL

$\left(\mathrm{UL}^{\mathrm{T}}\right)^{1 / \mathrm{p}}$

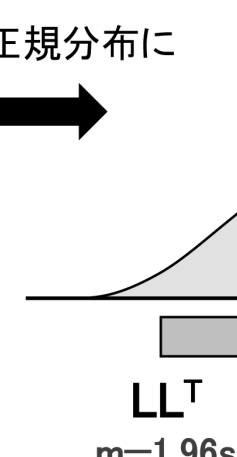

$\mathrm{m}-1.96 \mathrm{~s}$ $\mathrm{m}$ : 平均

s: SD

(3)上限值·下限值を

逆変換し 基準範囲とする

(2) $m \pm 1.96 s$ から 95\%信頼区間を算出

図2 調整Box-Coxべき乗変換式を用いたパラメトリック法

計測值の分布が歪む場合，(1)べき乗変換で正規分布に変換した後に

(2)変換後の平均值 $\mathrm{m}$, 標準偏差 $\mathrm{s}$ より, 分布の $95 \%$ 信頼区間を $\mathrm{m} \pm 1.96 \mathrm{~s}$ として算出.

(3)その信頼区間の下限值LLT と上限值ULTを逆変換をすることで変換前の基準範囲

の下限值 LLと上限值ULを算出する。 LL : 下限值, Me : 中央值, UL：上限值. 
表 2 非術側膝筋力と関節可動域の変動要因を分析するための重回帰分析

\begin{tabular}{|c|c|c|c|c|c|c|c|}
\hline & & $\mathrm{R}$ & 性別 & 年齢 & BMI & 運動習慣 & 両側性 \\
\hline \multirow[t]{4}{*}{ a. 術前 } & 膝伸展筋力 & 0.337 & 0.27 & -0.17 & -0.10 & 0.08 & 0.00 \\
\hline & 膝屈曲筋力 & 0.306 & 0.22 & -0.18 & -0.13 & 0.01 & -0.07 \\
\hline & 膝伸展関節可動域 & 0.273 & 0.02 & -0.01 & -0.13 & 0.05 & -0.21 \\
\hline & 膝屈曲関節可動域 & 0.369 & 0.00 & -0.03 & -0.26 & 0.03 & -0.23 \\
\hline \multirow[t]{4}{*}{ b. 術後 } & 膝伸展筋力 & 0.382 & 0.27 & -0.25 & -0.16 & 0.02 & 0.00 \\
\hline & 膝屈曲筋力 & 0.340 & 0.20 & -0.25 & -0.13 & -0.01 & -0.07 \\
\hline & 膝伸展関節可動域 & 0.177 & 0.01 & -0.02 & -0.06 & 0.04 & -0.15 \\
\hline & 膝屈曲関節可動域 & 0.358 & 0.03 & -0.05 & -0.25 & 0.00 & -0.23 \\
\hline
\end{tabular}

$\mathrm{R}$ : 重相関係数, BMI : Body Mass Index, 運動習慣 : 定期的な運動習慣を示す 2 值変数, 両側性 : 非術側の変 形の有無を示す 2 值変数. 標準偏回帰係数 ( $\mathrm{rp}$ ) は-1.0 1.0 の值で表示, $|\mathrm{rp}| \geq 0.2$ の効果量を超える值は太 字にて強調.

合は，測定值分布の 2.5 97.5 パーセンタイルの範囲に よるノンパラメトリック法により設定した。統計解析に はStatFlexV7 を使用した。

倫理的配慮, 説明, および同意については,「ヘルシ ンキ宣言」と「臨床研究に関する倫理指針」に従った。 対象者には研究内容を書面で説明をし, 十分に理解した うえで同意書を得た。なお常葉大学倫理委員会（承認番 号：変-2018-501H）の承認を得て実施した。

\section{III. 結 果}

術前の筋力と関節可動域の変動要因を分析するため重 回帰分析を実施した。表 $2 \mathrm{a}$ に示すように， $|\mathrm{rp}|>0.2$ で あったのは, 筋力は性別 $(\mathrm{rp}=0.27, \mathrm{rp}=0.22)$ であった. また膝関節可動域においては, 両側性 $(\mathrm{rp}=-0.21$, $\mathrm{rp}=-0.23)$ であり, 片側性に対し両側性であると関節 可動域が低下していた。 さらに, 膝屈曲可動域は BMI $(\mathrm{rp}=-0.26)$ が関連しており, BMI が高いほど膝屈曲 可動域は低下していた。

術後も術前と同様に変動要因を重回帰分析により分析 した．表 $2 \mathrm{~b}$ に示すように， $|\mathrm{rp}|>0.2$ であったのは，膝 筋力においては性別 $(\mathrm{rp}=0.27, \mathrm{rp}=0.20)$ であった. また年齪が膝筋力に負の関連性を示し $(\mathrm{rp}=-0.25$, $\mathrm{rp}=-0.25)$, 年齢が高いほど筋力が低かった. 膝屈曲 可動域は術前と同様にBMI $(\mathrm{rp}=-0.25)$ と両側性 $(\mathrm{rp}=-0.23)$ が, 負の関連を示した.つまり BMI が高く 両側性であるほど膝屈曲関節可動域は低かった。

図 3 では，膝伸展筋力（図 3A） と膝屈曲筋力（図 3B) の測定值を, 性別にて層別化し，健常者と膝 OA 患者の 非術側の值を比較した。男性よりも女性の筋力值が低い ことは，全てのグループにおいて明らかであった。ただ し年齢も関連性を認めたが，年齢よりも性別との関連が

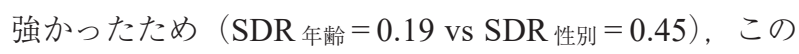
図では性別により層別化している。また図 $3 \mathrm{~A} に$ に示した
中央 $50 \%$ 範囲と中央值を比較すると, 非術側の膝伸展 筋力においては健常者と比較して特に低值であった.

図 4 では，溙 OA 患者の滕伸展関節可動域（図 4A） と膝屈曲可動域（図 4B）の測定值を, 両側性か片側性 かで層別化し，その測定值を健常者と比較した。非術側 に障害のある両側性の場合は, 片側性と比較して関節可 動域が低下していることは明らかであった。ただ関節 可動域も, BMIが関連していたが, BMIより両側性と の関連が強かったため $\left(\mathrm{SDR}_{\mathrm{BMI}}=0.15 \mathrm{vs} \mathrm{SDR}_{\text {両側性 }}=\right.$ 0.35), この図では両側性かどうかで層別化している. また図 4Bに示した分布の最頻值を比較すると, 非術側 の膝屈曲関節可動域においては健常者と比較して特に低 值であった。

層別化して基準範囲を設定すべき要因の評価について, 性別, 年齢, BMI，および両側性に対して検討した。術 前の測定值については, 性別, BMI, 両側性によって, 術後は重回帰分析により 4 つの要因が抽出されたため, 性別，BMI，両側性で検討した後に，さらに性別，年齢， 両側性によって 3 レベルの枝分かれ分散分析を実施し た。表 3 に示すように, SDR $\geq 0.3$ を層別化の基準とし た場合, それを超えたのは, 術前の非術側膝伸展筋力と 非術側膝屈曲筋力の SDR 性別, 各々 0.46 と 0.35 , 非術 側の膝伸展関節可動域と膝屈曲可動域の SDR 両側性, 各々 0.36 と 0.35 であった。 そのため非術側の筋力は性 別により，関節可動域は両側性と片側性に層別化するべ きと判断した.

術後の非術側の膝伸展筋力と関節可動域を性別, BMI, 両側性について同様に検討した結果，SDR が層別化の基 準を超えたのは, 非術側膝伸展筋力と非術側膝屈曲筋力 の $\mathrm{SDR}$ 性別 0.45 と 0.30 , また膝屈曲関節可動域の SDR 両 側性 0.35 であった。 さらに性別, 年齢, 両側性に対して も分析した結果, 非術側膝伸展筋力の SDR 性別は 0.43 , 膝屈曲関節可動域の SDR 両側性は 0.38 であった。術後の SDR が 0.3 未満の検査も認めたが, 術前の層別化と一貫 
A

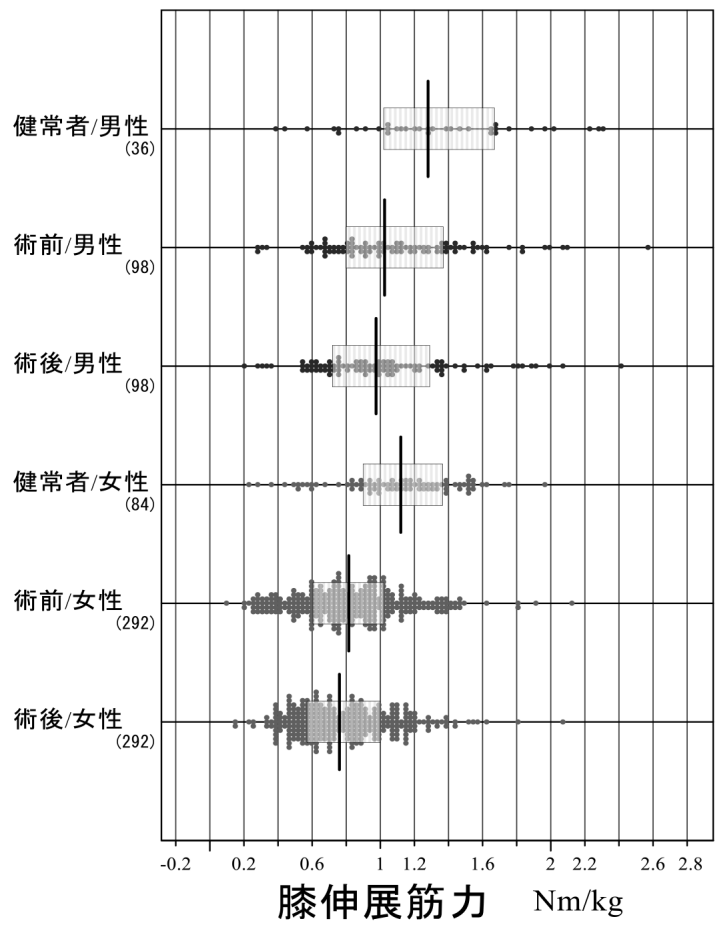

B

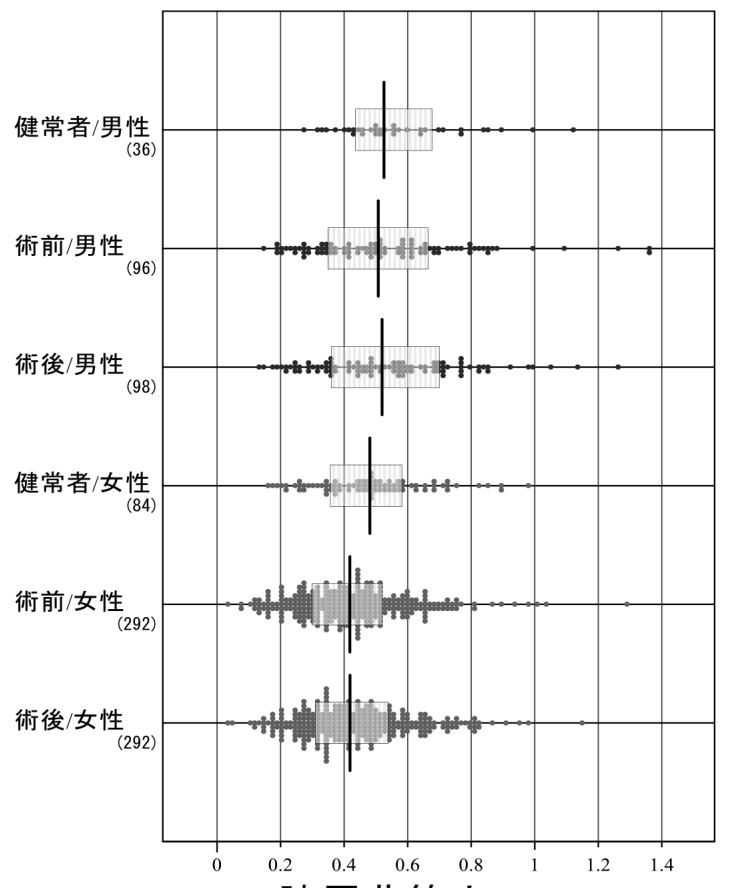

膝屈曲筋力 $\mathrm{Nm} / \mathrm{kg}$

図 3 膝筋力の性別による層別化図

膝伸展筋力 $(\mathrm{A})$ と膝屈曲筋力 $(\mathrm{B})$ の測定值を, 性別にて層別化し, 健常者と膝OA患者の非術側の值を比較した. ボックスと中央線は, 各グループでの中央 $50 \%$ 範囲と中央值を表示.
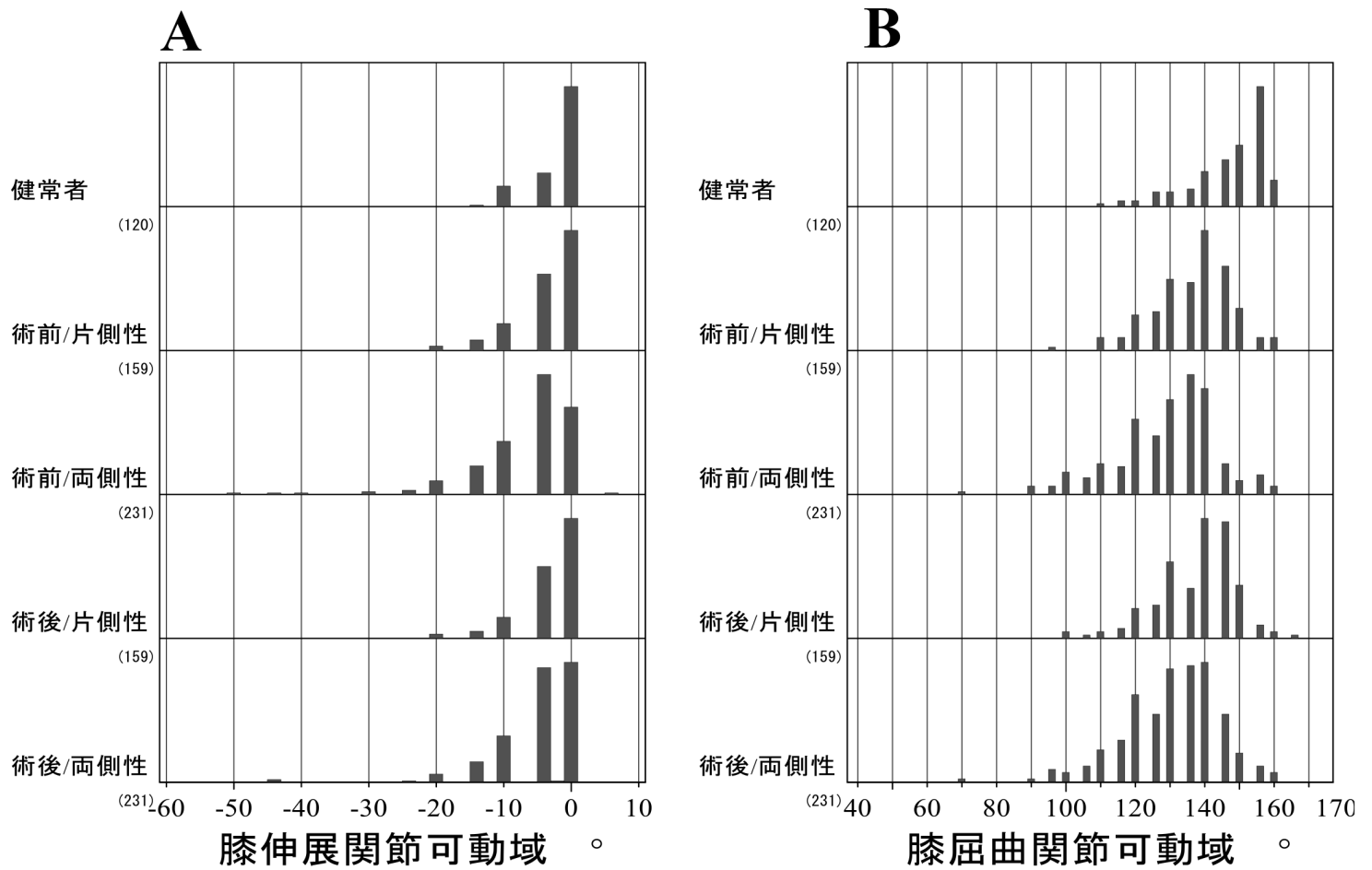

図4 膝関節可動域の両側性と片側性による層別化図

膝伸展関節可動域 (A) と膝屈曲可動域 (B) の測定値を, 両側性・片側性で層別化し, 健常者と膝OA患者の非 術側の值を比較した。

測定は 5 ごとの離散量で記録されるため，その分布をヒストグラム形式で示す． 
表 3 層別化の必要性を評価するための SDR

\begin{tabular}{|c|c|c|c|c|c|c|}
\hline & \multicolumn{3}{|c|}{ 術前 } & & & \\
\hline & SDR 性別 & $\mathrm{SDR}_{\mathrm{BMI}}$ & SDR 両側性 & & & \\
\hline 膝伸展筋力 & 0.46 & 0.00 & 0.00 & & & \\
\hline 膝屈曲筋力 & 0.35 & 0.03 & 0.09 & & & \\
\hline 膝伸展関節可動域 & 0.00 & 0.00 & 0.36 & & & \\
\hline \multirow[t]{3}{*}{ 膝屈曲関節可動域 } & 0.00 & 0.15 & 0.35 & & & \\
\hline & \multicolumn{3}{|c|}{ 術後 } & \multicolumn{3}{|c|}{ 術後 } \\
\hline & SDR 性別 & $\mathrm{SDR}_{\mathrm{BMI}}$ & $\mathrm{SDR}_{\text {両側性 }}$ & SDR 性別 & $\mathrm{SDR}$ 年齢 & $\mathrm{SDR}_{\text {両側性 }}$ \\
\hline 膝伸展筋力 & 0.45 & 0.11 & 0.07 & 0.43 & 0.26 & 0.00 \\
\hline 膝屈曲筋力 & 0.30 & 0.16 & 0.15 & 0.29 & 0.18 & 0.24 \\
\hline 膝伸展関節可動域 & 0.00 & 0.00 & 0.18 & 0.00 & 0.00 & 0.19 \\
\hline 膝屈曲関節可動域 & 0.00 & 0.08 & 0.35 & 0.00 & 0.00 & 0.38 \\
\hline
\end{tabular}

SDR：群間差指数. 術前の測定值は, 性別, BMI, 両側性によって, 術後は 4 つの要因が抽 出されたため, 性別, BMI, 両側性で検討した後に, 性別, 年齢, 両側性によって 3 レベル の枝分かれ分散分析を実施. SDR $\geq 0.3$ を超える值は太字にて強調.

性を保つために，非術側の膝筋力は性別により，膝関節 可動域は両側性と片側性別に層別化することとした。

基準範囲をパラメトリック法で設定する前提条件とし て，図 5 と図 6 に示すように，正規確率紙と K-S test に より, 非術側の膝伸展筋力と膝屈曲筋力のべき乗変換に よる正規分布化の達成を確認した。一方，図 $4 \mathrm{~A}$ と図 $4 \mathrm{~B}$ に示すように, 膝伸展関節可動域と屈曲関節可動域

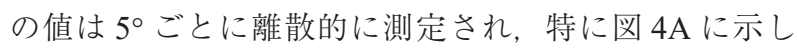
た膝伸展可動域は低值側（マイナス側）に大きく歪みを 認めた。このため関節可動域の基準範囲は, ノンパラメ トリック法により測定值分布の 2.5 97.5 パーセンタイ ルの範囲として設定した。

設定した基準範囲は, 表 4 に 4 つの測定項目に分けて 提示した。筋力はパラメトリック法により, 関節可動域 はノンパラメトリック法によって設定されたことに注意 が必要である。また健常者の基準範囲はサンプル数が 120 例と小さく, 設定精度が低下するため 10$)$, あえて 層別化しなかった.

\section{IV. 考 察}

片側性人工膝関節患者において，非術側の膝関節筋力 や関節可動域は, 術後の運動機能や生活動作能力を改善 させるうえで重要な要因となる。そのため非術側膝を検 査・測定することは, 術後管理を実施するうえで重要と なる。

検査・測定した際に，検査值を判断する基準となる值 (基準值) として，平均值と標準偏差が示されてきた。ま た近年は，測定值の中央 $95 \%$ の区間として「基準範囲」 の名称が使われている。しかし，基準值や基準範囲を設
定するうえで重要となる計測値の分布型が考慮されてい ない.さらに関節可動域測定の基準值は, 測定值の変動 要因の分析と層別化の妥当性が検討されていない。 そし て健常者の基準值に加えて, 病態を有する膝 OA 患者固 有の非術側の筋力や関節可動域の基準值が必要である.

非術側の膝筋力と関節可動域の変動要因と層別化につ いて考察する。まず術前と術後における非術側の膝伸展 筋力と膝屈曲筋力には性別が影響しており，男性と比較 して女性の筋力が低下していた。その理由として, Danneskiold-Samsøe ら 7)は，20 代から 70 代までの健 常者 443 名（男性 138 名，女性 305 名）を対象に，等 尺性筋力を測定した結果, 男性の筋力が女性の 1.5 倍か ら 2 倍の測定值であったと報告した。また Logerstedt ら 15) は, 膝 OA 患者を対象として筋力值に影響する要 因を検討しており，膝筋力には性差が影響していたと報 告した。すなわち健常高齢者と膝 OA 患者の筋力值は, 性別により異なることが示された。ささらに本研究の結果 では, 膝伸展・屈曲筋力における SDR 性別が高いことか ら，膝筋力の基準範囲は男女で層別化をするのが妥当で あると判断した。

一方で, 膝関節症が両側性であることの非術側膝筋力 への影響については, Riceら 16) が, 滕 OAにより生じ る筋力低下は, 関節の損傷に伴い関節周辺の正常な筋に 神経抑制が起こり, 筋力低下が生じたと報告しており, 片側性障害に比べて両側性障害の膝筋力が低下すると推 察された。しかし変動要因分析の結果, 両側性と片側性 の違いは筋力の変動に影響していなかった。 その理由と して, 両側性の非術側膝は, 術側に比べて OAの重症度 が軽度であることが推察される。そして Thomasら ${ }^{17) か ゙, ~}$ 大腿四頭筋の筋力は, K-L 分類 $\cdot \operatorname{grade} 2$ の膝 OA 群と 

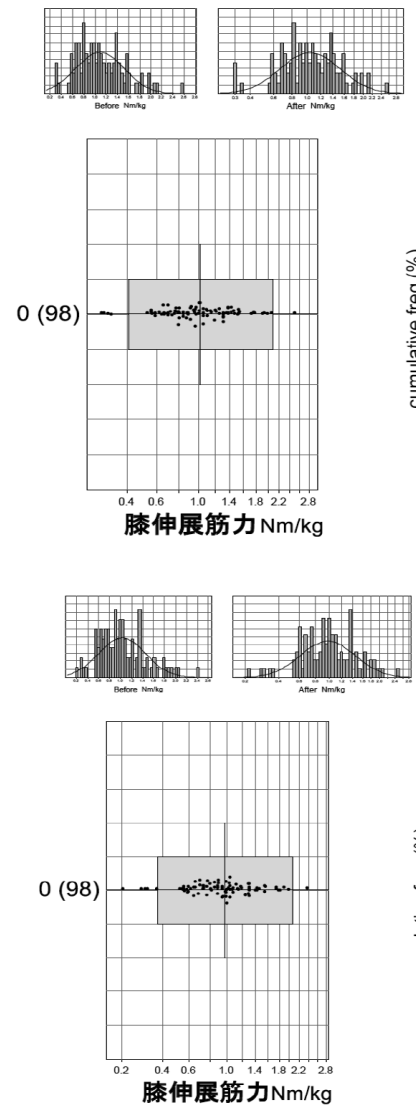
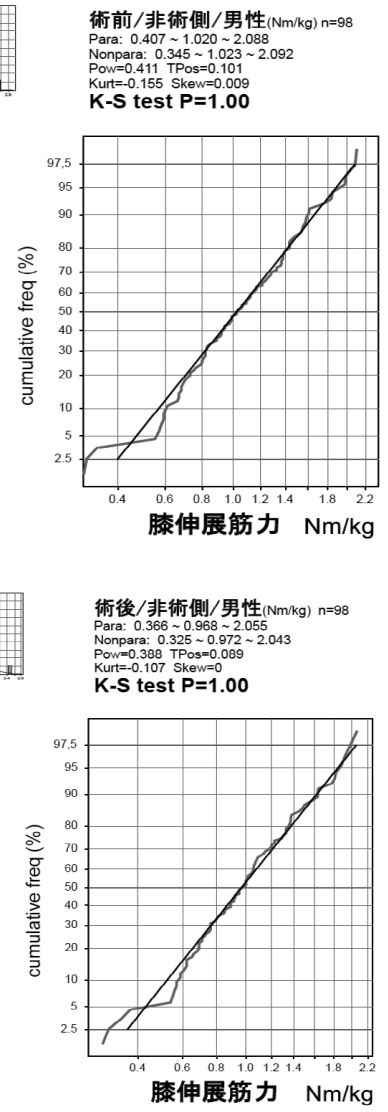

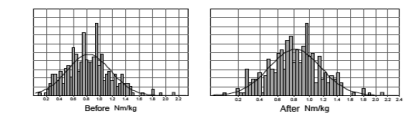

術前/非術側/女性( $(\mathrm{Nm} / \mathrm{kg}) \mathrm{n}=292$

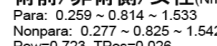
Pow $=0.723$ TPos= $=0.026$
Kurt=-0.457 Skew $=0.157$ Kurt=-0.457 Skew $=0.157$
$K-S$ test $P=1.00$
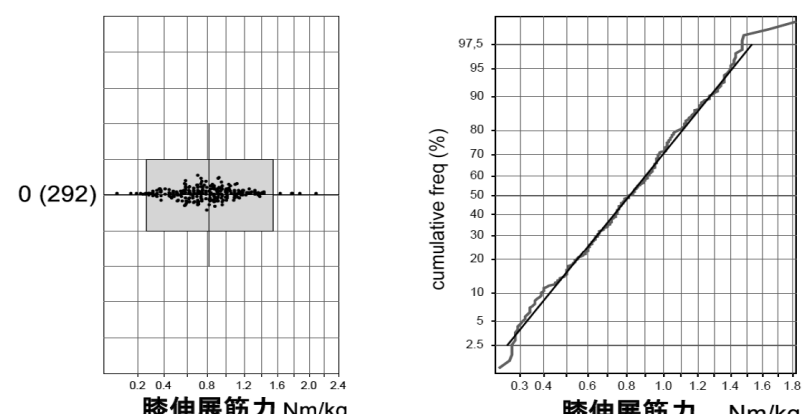

膝伸展筋力 $\mathrm{Nm} / \mathrm{kg}$
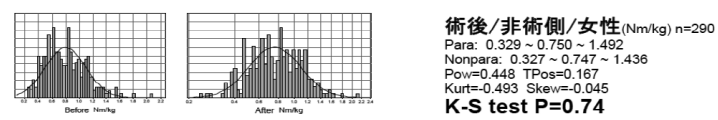
Para: $0.329 \sim 0.750 .11 .492$
Nonpara: $0.237 \sim 0.747-1.436$
Pow $=0.448 .703=0.167$ Kurte-0.493 Skew $=0.04$

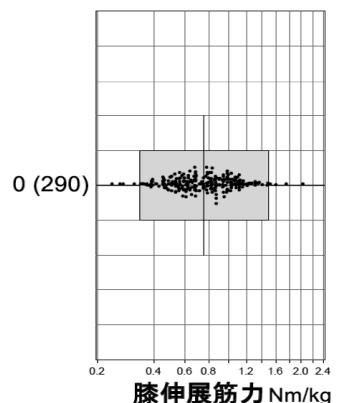

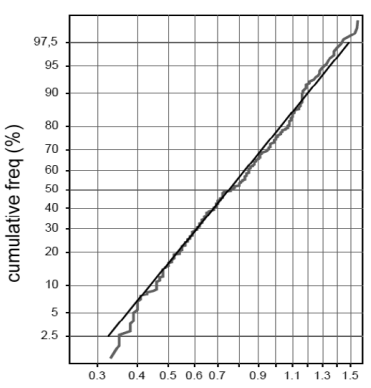

膝伸展筋力 $\mathrm{Nm} / \mathrm{kg}$

図５パラメトリック法による滕伸展筋力の基準範囲設定と分布の正規化の確認

べき乗変換による正規分布への変換の妥当性は，正規確率紙による累積度数曲線中央部の直線性と Kolmogorov-Smirnov検 定 (K-S test)により行った.

K-L 分類・grade 0 から 1 の対照群には, 筋力值に差を 認めなかったと報告していることから，両側性の非術側 膝はOAの重症度が軽度であったため, 両側性と片側性 とでは筋力值に差異を認めなかったと考えられた。

それに対して非術側の関節可動域については, 変動要 因分析の結果, 両側性と片側性の違いが関節可動域の変 動に影響しており，片側性に比べて両側性では低下して いた。 Nishimuraら 18) は, 膝 OA の発生率と進行率を 調査し, 変形の進行と膝関節の関節可動域が有意に関連 していたと報告した。さらに種継ら19)は, 早期の膌 OA が関節可動域に影響するかについて検討しており, grade 1 と grade 2 との関節可動域に差を認め, 早期の $\mathrm{OA}$ が関節可動域低下のリスク因子であることを報告し た。すなわち膝筋力とは異なり, 関節可動域には早期の OA が影響することから，両側性と片側性とでは関節可 動域に差異があることが示された。ささらに膝伸展・屈曲 可動域における SDR 両側性が高いことから, 膝関節可動 域の基準範囲は，両側性と片側性別に層別化するのが妥 当であると判断した。

次に，基準範囲を設定するためのパラメトリック法の
信頼性について考察する。過去に健常者を対象に設定さ れた膝筋力の基準值が報告されている. Andrews ら 8)は, 健常者 156 名（男性 77 名, 女性 79 名）を対象に年齢 別の等尺性膝筋力の平均值（SD）を報告している。 そ の基準值はパラメトリック法により設定されているのに もかかわらず，分布型が考慮されていなかった。また Neder ら 20) は, 健常者 96 名（男性 45 名, 女性 51 名) を対象に等速性膝筋力の平均值（SD）を報告している. この基準值についても，パラメトリック法を用いるうえ で必要となる分布型の検討がなされていなかった。その ため測定值が正規分布しない場合は，適切な基準值を設 定できないことが問題となる。さらにDanneskioldSamsøe ら 7) は, 健常者 189 名（男性 63 名, 女性 126 名) を対象に，年齢と性別で層別化した等尺性筋力の平均值 と中央值を報告した。この基準值はサブグループでのサ ンプル数が男性 9〜11名, 女性 18〜23 名と, 最小デー 夕数とされる 120 名よりも遙かに少ないため, 基準值 の設定精度が極端に低い10)ことが問題となる.

さらにこれらの基準值の対象が健常者であることから, 膝 OA 患者の測定值の分布型とは異なる可能性があり, 

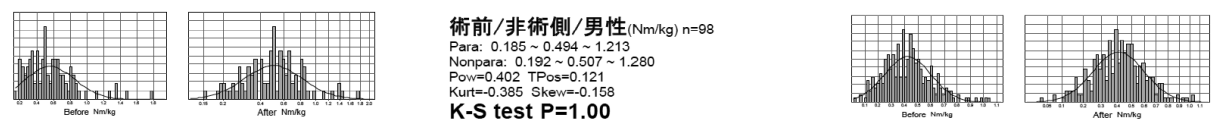

術前/非術側/女性( $(\mathrm{Nm} / \mathrm{kg}) \mathrm{n}=291$ K-S test $P=1.00$
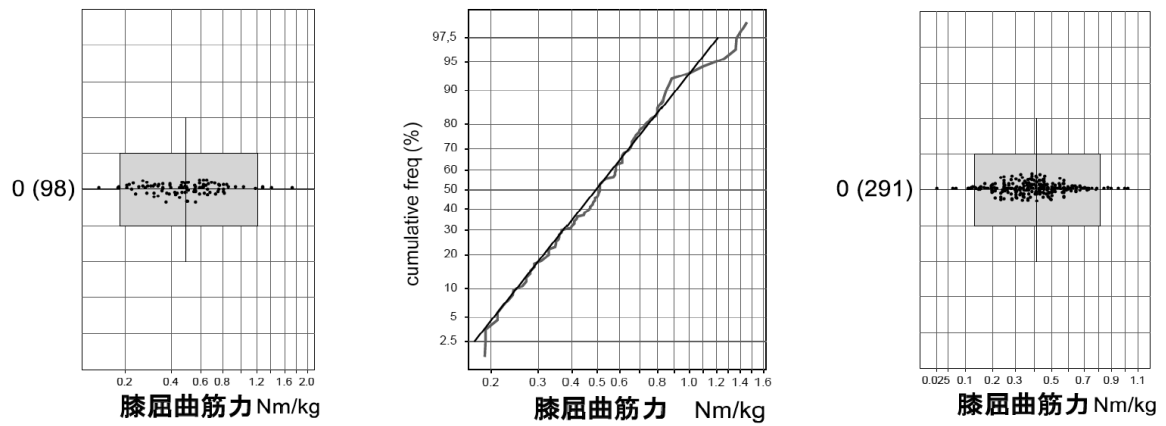

Nonpara: 0. $0.130 .0 .412 \sim 0.809$ Kurt=-0.311 Skew $=0.099$
K-S test $P=0.96$

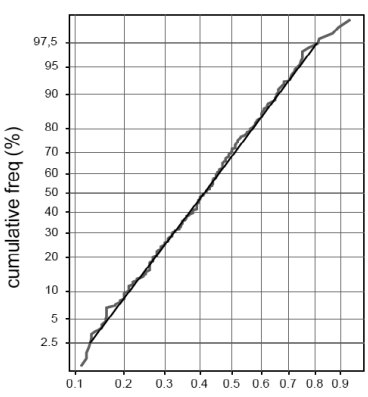

㯃㞑曲筋力 $\mathrm{Nm} / \mathrm{kg}$

膝屈曲筋力 $\mathrm{Nm} / \mathrm{kg}$

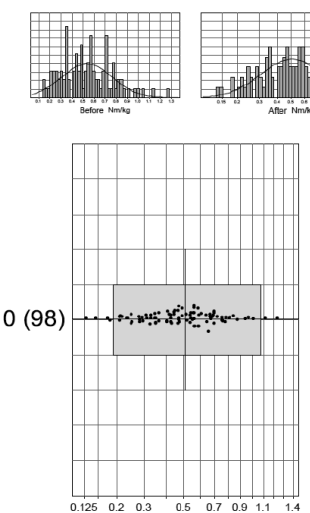

溙届曲筋力 $\mathrm{Nm} / \mathrm{kg}$
術後/非術側/男性 $(\mathrm{Nm} / \mathrm{kg}) \mathrm{n}=98$ Para: $0.188 \sim 0.509 \sim 1.078$
Nonpara: $0.180 \sim 0.529 \sim 1.033$

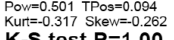

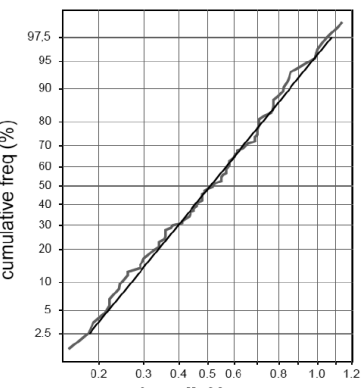

䐂屈曲筋力 $\mathrm{Nm} / \mathrm{kg}$

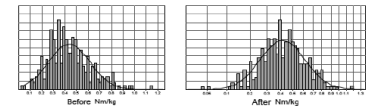

術後/非術側/女性( $(\mathrm{Nm} / \mathrm{kg}) \mathrm{n}=292$ Para: $0.148 \sim 0.414 \sim 0.845$ Pow $=0.491$
Kurt=- 0.309
Sks $\mathrm{K}-\mathrm{S}$ test $\mathrm{P}=\mathbf{1 . 0 0}$
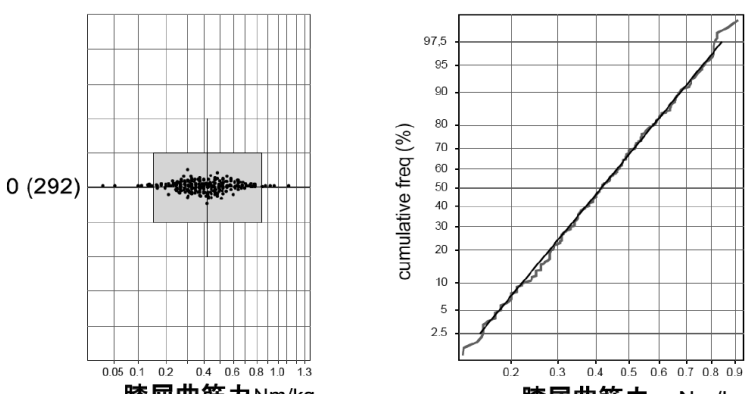

膝届曲筋力 $\mathrm{Nm} / \mathrm{kg}$

図6 パラメトリック法による膝屈曲筋力の基準範囲設定と分布の正規化の確認

べき乗変換による正規分布への変換の妥当性は, 正規確率紙による累積度数曲線中央部の直線性とKolmogorovSmirnov検定 (K-S test)により行った.

表 4 膝筋力と関節可動域の基準範囲

パラメトリック基準範囲

\begin{tabular}{|c|c|c|c|c|c|c|c|c|}
\hline & & & \multicolumn{3}{|c|}{ 滕伸展筋力 $(\mathrm{Nm} / \mathrm{kg})$} & \multicolumn{3}{|c|}{ 膝屈曲筋力 $(\mathrm{Nm} / \mathrm{kg})$} \\
\hline & 性別 & $\mathrm{n}$ & LL & $\mathrm{Me}$ & UL & LL & $\mathrm{Me}$ & UL \\
\hline \multirow[t]{3}{*}{ 健常者 } & 男女 & 120 & 0.37 & 1.16 & 2.00 & 0.21 & 0.49 & 0.93 \\
\hline & 男 & 36 & --- & 1.28 & --- & --- & 0.53 & --- \\
\hline & 女 & 84 & --- & 1.12 & --- & --- & 0.48 & --- \\
\hline \multirow[t]{2}{*}{ 術前 } & 男 & 98 & 0.41 & 1.02 & 2.09 & 0.18 & 0.49 & 1.21 \\
\hline & 女 & 291 & 0.26 & 0.81 & 1.53 & 0.13 & 0.41 & 0.81 \\
\hline \multirow[t]{2}{*}{ 術後 } & 男 & 98 & 0.37 & 0.97 & 2.06 & 0.19 & 0.51 & 1.08 \\
\hline & 女 & 291 & 0.33 & 0.75 & 1.49 & 0.15 & 0.41 & 0.85 \\
\hline
\end{tabular}

ノンパラメトリック基準範囲

\begin{tabular}{|c|c|c|c|c|c|c|c|c|c|}
\hline & & \multirow[b]{2}{*}{ 性別 } & \multirow[b]{2}{*}{$\mathrm{n}$} & \multicolumn{3}{|c|}{ 膝伸展関節可動域（o） } & \multicolumn{3}{|c|}{ 溙屈曲関節可動域 (o) } \\
\hline & & & & LL & $\mathrm{Me}$ & UL & LL & $\mathrm{Me}$ & UL \\
\hline \multirow{3}{*}{$\begin{array}{l}\text { 健常者 } \\
\text { 術前 }\end{array}$} & & 男女 & 120 & -10 & 0 & 0 & 120 & 150 & 160 \\
\hline & 片側性 & 男女 & 159 & -15 & 0 & 0 & 110 & 140 & 155 \\
\hline & 両側性 & 男女 & 231 & -25 & -5 & 0 & 95 & 130 & 155 \\
\hline \multirow[t]{2}{*}{ 術後 } & 片側性 & 男女 & 159 & -15 & 0 & $0 *$ & 110 & 140 & $155^{*}$ \\
\hline & 両側性 & 男女 & 231 & -20 & -5 & 0 & 95 & 130 & $155^{*}$ \\
\hline
\end{tabular}

$\mathrm{LL}$ ：下限值， $\mathrm{Me}$ ：中央值， UL：上限值，設定した基準範囲は，筋力はパラメトリック法により，関節可動域 はノンパラメトリック法によって設定. * : 術前と差異なし. 
本研究の結果では, 膝 OA 患者の分布型には歪みを認め ている。そのため滕 OA 患者固有の基準範囲の設定には 分布型を考慮した設定方法が必要となる。本研究により 設定された基準範囲は，正規確率紙と K-S testにより， べき乗変換による正規分布化の達成を確認しており, 必 要なサンプル数も確保されていることから，信頼性の高 い基準範囲であるといえる。一方, 関節可動域について

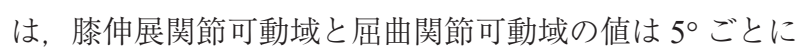
離散的に測定され，低值側に大きな歪みを認めた。この ため, 関節可動域の基準範囲は，ノンパラメトリック法 により測定值分布の 2.5 97.5 パーセンタイルの範囲と して設定した。また設定した基準範囲のなかで，片側性 の膝伸展可動域と膝屈曲関節可動域は, 術前と術後の基 準範囲の差異を認めなかったが, 便宜上分けて標記した。

健常者の膝筋力や関節可動域の基準值が報告されてい るものの, 本結果の測定值においても非術側にもかかわ らず，健常者と比較して低值を示していることから，整 形外科およびリハビリテーション分野で必要となるのは 膝 $\mathrm{OA}$ 患者に固有の基準範囲である. 本研究の基準範囲 を活用することで，臨床で検査された対象者の測定值が 設定された基準範囲の範囲外であるのか, または下限值 - 中央值 - 上限值のどの範囲に位置するかについて解釈 が可能となる。それにより膝 OA 患者の非術側の機能評 価を的確に実施でき, 術前・術後のリハビリテーション において，機能評価や予後予測に役立つと考える.

本研究の限界として, 人工膝関節置換術を受けた膝 OA 患者の長期管理のためには, 膝機能を長期的に評価 する必要があるが, 本研究では長期追跡が困難であった ため, 術後 14 日目の筋力と関節可動域に限定して測定 する必要があった。 そのため本報告の基準範囲は, 術前 と術直後のリハビリテーションでの使用には有効である ものの, 長期のフォローアップでの有用性は不明である. 今後の展望として, 長期間フォローアップをしたうえで, 術後長期での基準範囲の設定に取り組む必要がある.

また健常者の基準範囲は，サンプル数が 120 例と小 さく層別化できていないため, 健常高齢者の対象者数を 増やし, 層別化しても設定精度が低下しない基準範囲を 設定することも必要になる。そのため健常者を対象とし た大規模な調査を計画していく必要がある.

利益相反 本論文発表内容に関して申告すべき利益相反 はない.

\section{引用文献}

1) Yoshimura N, Muraki S, Oka H, et al.: Prevalence of knee osteoarthritis, lumbar spondylosis, and osteoporosis in Japanese men and women: the research on osteoarthritis/ osteoporosis against disability study. J Bone Miner Metab, 2009, 27: 620-628.
2) 山本慶太郎, 勝呂 徹 : 現在の人工膝関節市場. Bone Jt Nerve, 2015, 15: 11-18.

3) Mizner RL, Petterson SC, Stevens JE, et al.: Preoperative quadriceps strength predicts functional ability one year after total knee arthroplasty. J Rheumatol, 2005, 32: 1533-1539.

4) Zeni JA Jr, Snyder-Mackler L: Early postoperative measures predict 1- and 2-year outcomes after unilateral total knee arthroplasty: importance of contralateral limb strength. Phys Ther, 2010, 90: 43-54.

5) Valtonen A, Pöyhönen T, Heinonen A, et al.: Muscle deficits persist after unilateral knee replacement and have implications for rehabilitation. Phys Ther, 2009, 89: 1072-1079.

6) 内田茂博, 玉利光太郎, 横山茂樹 - 他 : 人工膝関節置換 術後早期に扮ける運動機能予測因子の検討. 理学療法学, 2011, 38: 442-448.

7) Danneskiold-Samsøe B, Bartels EM, Bülow PM, et al.: Isokinetic and isometric muscle strength in a healthy population with special reference to age and gender. Acta Physiol (Oxf), 2009, 197: 1-68.

8) Andrews AW, Thomas MW, Bohannon RW: Normative values for isometric muscle force measurements obtained with handheld dynamometers. Phys Ther, 1996, 76: 248-259.

9) 米本恭三, 石神重信, 近藤 徹：関節可動域表示ならびに 測定法.リハビリテーション医学, 1995, 32: 207-217.

10) Ichihara K, Boyd JC, IFCC Committee on Reference Intervals and Decision Limits (C-RIDL): An appraisal of statistical procedures used in derivation of reference intervals. Clin Chem Lab Med, 2010, 48: 1537-1551.

11) Bohannon RW: Comfortable and maximum walking speed of adults aged 20-79 years: reference values and determinants. Age Ageing, 1997, 26: 15-19.

12) Katoh M, Yamasaki H: Comparison of reliability of isometric leg muscle strength measurements made using a hand-held dynamometer with and without a restraining belt. J Phys Ther Sci, 2009, 21: 37-42.

13) Cohen J: A power primer. Psychol Bull, 1992, 112: 155-159.

14) 市原清志: 基準範囲・臨床判断值. 臨床検査ガイドライン. JSLM, 2018, 2018: 12-22.

15) Logerstedt DS, Zeni J Jr, Snyder-Mackler L: Sex differences in patients with different stages of knee osteoarthritis. Arch Phys Med Rehabil, 2014, 95: 2376-2381.

16) Rice DA, McNair PJ: Quadriceps arthrogenic muscle inhibition: neural mechanisms and treatment perspectives. Semin Arthritis Rheum, 2010, 40: 250-266.

17) Thomas AC, Sowers M, Karvonen-Gutierrez C, et al.: Lack of quadriceps dysfunction in women with early knee osteoarthritis. J Orthop Res, 2010, 28: 595-599.

18) Nishimura A, Hasegawa M, Kato K, et al.: Risk factors for the incidence and progression of radiographic osteoarthritis of the knee among Japanese. Int Orthop, 2011, 35: 839-843.

19) 種継真輝, 寺山佳佑, 田村滋規 - 他 : 早期 - 初期変形性膝 関節症における変形重症度分類に影響を及ぼす因子の検討。 ヘルスプロモーション理学療法研究, 2019, 9: 71-76.

20) Neder JA, Nery LE, Shinzato GT, et al.: Reference values for concentric knee isokinetic strength and power in nonathletic men and women from 20 to 80 years old. J Orthop Sports Phys Ther, 1999, 29: 116-126. 